\begin{tabular}{lllllllllllllllll}
$\mathrm{S}$ & $\mathrm{T}$ & $\mathrm{U}$ & $\mathrm{D}$ & $\mathrm{I}$ & $\mathrm{A}$ & & $\mathrm{T}$ & $\mathrm{E}$ & $\mathrm{M}$ & $\mathrm{A}$ & $\mathrm{T}$ & $\mathrm{Y}$ & $\mathrm{C}$ & $\mathrm{Z}$ & $\mathrm{N}$ & $\mathrm{E}$ \\
\hline
\end{tabular}

STUDIA Z PRAWA WYZNANIOWEGO

Tom $21-2018$

DOI: https://doi.org/10.31743/spw.191

AGNIESZKA FILAK*

\title{
CHARAKTER PRAWNY SŁUŻBY DUCHOWNEGO W KOŚCIELE EWANGELICKO-AUGSBURSKIM W RZECZYPOSPOLITEJ POLSKIEJ
}

\section{Streszczenie}

Przedmiot niniejszego opracowania stanowi przedstawienie charakteru prawnego służby duchownego - diakona, wikariusza i proboszcza - w Kościele Ewangelicko-Augsburskim w RP. Autorka świadomie rezygnuje z analizy statusu prawnego służby biskupa, jako że biskupi diecezjalni zasadniczo pełnią również funkcję proboszcza, co w istotnym stopniu przesądza o ich sytuacji formalnej. Podstawę analizy sytuacji prawnej służby duchownych stanowią akty prawa kościelnego, w tym przede wszystkim Zasadnicze Prawo Wewnętrzne oraz Pragmatyka Służbowa.

Urząd duchownego w Kościele Ewangelicko-Augsburskim pochodzi z ustanowienia Bożego, ale ma również swój wymiar prawny określony w Zasadniczym Prawie Wewnętrznym. Kościół luterański uznaje jeden urząd duchowny, który posiada trzy posługi: biskupa, prezbitera i diakona. Urząd kościelny nie jest hierarchiczny i każda z posług urzędu kościelnego jest sobie równa, chociaż różnią się od siebie zakresem obowiązków. Tym, co zespala posługi urzędu kościelnego, jest wspólne prawo do sprawowania władzy kluczy, a przez to w konsekwencji do odpuszczania i zatrzymywania grzechów, głoszenia Ewangelii i sprawowania sakramentów. Ordynacja nie ma charakteru sakramentalnego. Prawo kościelne określa warunki ordynacji, prawa i obowiązki duchownych, a także zasady powoływania na urząd oraz skreślenia z listy duchownych.

Słowa kluczowe: duchowny; diakon; wikariusz; proboszcz; prawo kościelne; Kościół Ewangelicko-Augsburski; kościoły i inne związki wyznaniowe

$$
* * * * *
$$

* LL.M., dyrektor Biura Konsystorza Kościoła Ewangelicko-Reformowanego w RP; członek Komisji ds. reformy prawa kościelnego KEA w RP oraz KER w RP, Warszawa, e-mail: agnieszka.filak@luteranie.pl. 
WPROWADZENIE

Przedmiotem rozważań podjętych w niniejszym artykule jest przedstawienie sytuacji prawnej duchownego - diakona, wikariusza i proboszcza - w Kościele Ewangelicko-Augsburskim (KEA) w Rzeczypospolitej Polskiej. Autor świadomie zrezygnował z analizy statusu prawnego służby biskupa, ponieważ biskupi diecezjalni zasadniczo pełnią również funkcję proboszcza, co w istotnym stopniu przesądza o ich sytuacji formalnej. Podstawę analizy sytuacji prawnej służby duchownych stanowią akty prawa kościelnego, w tym przede wszystkim: Zasadnicze Prawo Wewnętrzne oraz Pragmatyka Służbowa.

\section{ROZUMIENIE POSŁUGI DUCHOWNEGO W KOŚCIELE EWANGELICKO-AUGSBURSKIM}

Według nauki luterańskiej duchowny jest reprezentantem osoby Chrystusa poprzez sprawowanie w Kościele urzędu zwiastowania Słowa Bożego i udzielania sakramentów świętych. Czyni to $w$ miejsce $i w$ zastępstwie Chrystusa. Duchowny luterański jest sługą Słowa Bożego. Gdy pełni to podstawowe zadanie zgodnie z nauką Pisma Świętego i Ksiąg Wyznaniowych Kościoła Ewangelicko-Augsburskiego posiada władzę kluczy.

Artykuł X Artykułów szmalkaldzkich Lutra - O wyświęceniu, ordynacji i powołaniu - zawiera praktyczne rozwiązania dotyczące kwestii wyznaczania duchownych w Kościele do uporządkowanego sprawowania władzy kluczy. Urząd duchowny został ustanowiony, aby zachować porządek w Kościele. Ze względu na niezgodę ze strony biskupów wiernych Rzymowi na ordynowanie duchownych ewangelickich, Luter przyjął zupełnie nowy model wyznaczania posługujących w Kościele. Powszechne kapłaństwo wszystkich wierzących znajduje swój wyraz w ordynacji. Duchownych ordynuje bowiem społeczność Kościoła ${ }^{1}$. Ordynowany pozostaje w służbie Kościoła i nie może działać niezależnie od wspólnoty².

Pamiętać należy, że pełnienie urzędu duchownego nie różni się co do istoty od powszechnego kapłaństwa wszystkich wiernych, lecz jest szcze-

Artykuły Szmalkaldzkie 1999, 355.

2 Tamże. 
gólną postacią służby pełnionej w formie urzędu. Charakterystyczna dla posługi urzędu kościelnego jest wspólna władza do sprawowania władzy kluczy, a przez to do odpuszczania i zatrzymywania grzechów, głoszenia Ewangelii i sprawowania sakramentów.

Urząd kościelny nie jest kapłaństwem w znaczeniu sprawowania ofiary za grzechy, gdyż jedyną i wystarczającą ofiarę złożył Chrystus na krzyżu. Nie funkcjonuje on na wzór kapłaństwa lewickiego, znanego ze Starego Testamentu. Jest służbą Słowa Bożego do sprawowania władzy kluczy w imieniu Kościoła, tzn. do odpuszczania i zatrzymywania grzechów, głoszenia Ewangelii i udzielania sakramentów³. Urząd duchownego pochodzi z ustanowienia Bożego, ale ma także swój wymiar prawny, określony przez prawo wewnętrzne Kościoła i - po części - regulowany przez odpowiednie przepisy prawa państwowego.

Kościół Ewangelicko-Augsburski uznaje jeden urząd duchowny, który posiada trzy posługi: biskupa, prezbitera i diakona ${ }^{4}$. Urząd kościelny nie jest hierarchiczny, każda z posług urzędu kościelnego jest sobie równa, chociaż różni się w zakresie obowiązków. Tym, co spaja posługi urzędu kościelnego jest wspólna władza do sprawowania władzy kluczy, a przez to do odpuszczania i zatrzymywania grzechów, głoszenia Ewangelii i sprawowania sakramentów.

Kościół powołuje do każdej z trzech wymienionych wyżej posług poprzez ordynację (wyświęcenie). Ze względu na temat artykułu autor skoncentruje się na posłudze diakona i prezbitera, jako że od strony formalno-prawnej istnieją istotne analogie pomiędzy posługą prezbitera i biskupa. Różnice wynikają natomiast głównie ze specyfiki zadań związanych z zarządem nad diecezją, które to zadania nie pozostają w związku z tematem opracowania.

Pamiętać należy, że ordynacja na urząd - mimo iż znajduje uzasadnienie w słowach przykazania i obietnicy, a więc Słowie Bożym - nie ma jednak charakteru sakramentalnego ${ }^{5}$. Ordynację poprzedza ukończe-

3 Obrona wyznania augsburskiego 1999, 262-263.

4 §18 ust. 1 Zasadniczego Prawo Wewnętrzne Kościoła Ewangelicko-Augsburskiego w Rzeczypospolitej Polskiej z dnia 26 października 1996 r., tekst jedn. na dzień 1 stycznia 2017 r., https://bik.luteranie.pl/files/Prawo/2017-01-01ZPW-tekstujednolicony.pdf [dostęp: 8.12.2017], dalej: ZPW.

5 Milerski 2004, 12. 
nie wyższych studiów teologicznych, nie mniej jednak prawo kościelne nie wskazuje konkretnej uczelni, na której studia te mają być ukończone. W Polsce w praktyce najczęściej jest to Chrześcijańska Akademia Teologiczna w Warszawie. Studenci studiów teologicznych, których zamiarem jest w przyszłości praca w Kościele, są dodatkowo zobowiązani do uczestniczenia w kursach zorganizowanych przez kościelną jednostkę kształcenia ustawicznego (Instytut Pastoralny), a także do odbycia praktyk (I-III rok obozy młodzieżowe ${ }^{6}$; IV-V rok praktyki wakacyjne w parafii ${ }^{7}$ ) $\mathrm{w}$ minimalnym wymiarze trzech miesięcy ${ }^{8}$. Studenci odbywają również praktyki katechetyczne w czasie trwania roku szkolnego 9 .

Absolwent teologii, który chce podejść do pierwszego egzaminu kościelnego (pro venia concionandi), zdanie którego stanowi conditio sine qua non ordynacji, jest zobowiązany do odbycia okresu kandydackiego, który co do zasady nie trwa dłużej niż trzy lata ${ }^{10}$. Parafia, w której kandydat odbywa praktykę, jest zobowiązana zapewnić kandydatowi wynagrodzenie, obowiązkowe ubezpieczenie ZUS i mieszkanie ${ }^{11}$. Z punktu widzenia formalno-prawnego kandydat na duchownego świadczy na rzecz parafii usługi, zatem stosunek prawny między kandydatem a parafią jest regulowany albo przez umowę zlecenia, albo umowę o pracę. Ta ostatnia zasadniczo jest zawierana w przypadkach, kiedy kandydat zamieszkuje w parafii.

Do posługi diakona mogą być powołane przez wyświęcenie (ordynację) osoby (mężczyźni lub kobiety), które:

1) należą do Kościoła i wyznają jego zasady,

2) posiadają obywatelstwo polskie,

3) cieszą się nieposzlakowaną opinią,

4) wykazują się dobrym stanem zdrowia psychicznego i fizycznego,

5) wykazują się przygotowaniem i kompetencjami do służby, którą mają pełnić,

6 218 Pragmatyki Służbowej Kościoła Ewangelicko-Augsburskiego w Rzeczypospolitej Polskiej, tekst jedn. na dzień 1 stycznia 2017 r., https://bik.luteranie.pl/files/ Prawo/2017-01-01PragmatykaSubowa-tekstujednolicony.pdf [dostęp: 8.12.2017], dalej: PS.

$7 \$ 219$ ust. 1 PS.

$8 \$ 220$ PS.

$9 \quad \$ 222$ PS.

10 Por. §224 i 226 PS.

$11 \$ 230$ PS. 
6) zdali egzamin kościelny pro venia concionandi przed Kościelną Komisją Egzaminacyjną ${ }^{12}$.

Do posługi prezbitera w Kościele mogą być powołani przez wyświęcenie (ordynację) mężczyźni, którzy:

1) należą do Kościoła i wyznają jego zasady,

2) posiadają obywatelstwo polskie,

3) cieszą się nieposzlakowaną opinią,

4) wykazują się dobrym stanem zdrowia psychicznego i fizycznego,

5) ukończyli akademickie studia teologiczne przepisane Pragmatyką Służbową Kościoła,

6) zdali egzamin kościelny pro venia concionandi przed Kościelną Komisją Egzaminacyjną ${ }^{13}$.

Urząd duchownego w posłudze diakona pełnią w KEA zarówno kobiety, jak i mężczyźni. Ich działalność obejmuje:

a) pracę charytatywną,

b) pomocniczą służbę Słowa Bożego w parafii obejmującą między innymi: odprawianie nabożeństw $\mathrm{z}$ wygłaszaniem kazań, sprawowanie sakramentów świętych, udzielanie ślubów kościelnych, przewodniczenie pogrzebom, nauczanie kościelne wśród dzieci i młodzieży, pracę ewangelizacyjno-misyjną, pracę wśród różnych środowisk parafialnych, pracę w kancelarii parafialnej ${ }^{14}$.

Diakoni otrzymują ordynację diakonacką po ukończeniu wyższych studiów teologicznych, odbyciu okresu kandydackiego, zdaniu pierwszego egzaminu kościelnego oraz dopuszczeniu do ordynacji przez Konsystorz.

Decyzją biskupa diakon jest kierowany do parafii, która przedstawia Konsystorzowi do akceptacji warunki socjalno-bytowe dla diakona. W praktyce oznacza to, że diakona z parafią nie łączy umowa, choć parafia jest zobowiązana do wypłaty uposażenia i zapewnienia mieszkania. Od

\footnotetext{
$12 \S 18$ ust. 3 ZPW.

$13 \S 18$ ust. 2 ZPW.

$14 \S 36$ PS.
} 
otrzymanego uposażenia diakon odprowadza składki do ZUS na zasadach określonych w ustawie o systemie ubezpieczeń społecznych.

\subsection{WIKARIUSZ}

Wikariat jest okresem pomocniczej służby w Kościele a równocześnie - czasem praktycznego przygotowania i nauki do dalszej służby. Odbywany jest pod bezpośrednim nadzorem proboszcza. Co do zasady wikariat nie powinien trwać dłużej niż cztery lata. W trzecim roku po ordynacji, wikariusz jest zobowiązany do przystąpienia do drugiego egzaminu kościelnego pro ministerio.

Konsystorz z własnej inicjatywy lub na wniosek Rady Parafialnej przydziela parafii wikariusza. Proboszcz określa wikariuszowi zakres obowiązków oraz - w porozumieniu z Radą Parafialną - miejsce zamieszkania $^{15}$. Parafia przyjmująca wikariusza jest zobowiązana do przedstawienia Konsystorzowi do akceptacji warunków socjalno-bytowych wikariusza. Sytuacja prawna wikariusza jest zatem analogiczna do sytuacji diakona.

\subsection{PROBOSZCZ}

Na stanowisko proboszcza może być wybrany duchowny, który:

1) zdał egzamin pro ministerio przed Kościelną Komisją Egzaminacyjną,

2) posiada co najmniej 5 lat służby w Kościele, licząc od dnia ordynacji.

Wzajemne prawa i obowiązki proboszcza określa regulamin parafialny oraz wokacja. Wokacja to szczególny rodzaj umowy łączącej parafię i proboszcza. Na jej podstawie niewątpliwie świadczona jest praca za wynagrodzeniem, co więcej, biorąc pod uwagę fakt, że proboszcz na swoje stanowisko jest wybierany - praca ta jest świadczona osobiście. Można zatem odnieść wrażenie, że wokacja nosi znamiona umowy o pracę. Niemniej jednak praca ta nie jest świadczona pod kierownictwem, brak jest bowiem w parafii podmiotu, który mógłby wydawać proboszczowi wiążące polecenia. Stąd też brak jest trzeciej z esentialia negotii umowy o pracę.

15 Por. $\$ 41 \mathrm{ZPW}$. 
Prawo zna także inny przypadek, kiedy osoba świadcząca pracę jest pracownikiem, choć nie posiada ona bezpośredniego przełożonego - chodzi tu o członków zarządu spółek kapitałowych ${ }^{16}$.

Charakter prawny wokacji był przedmiotem rozważań Sądu Najwyższego, który w orzeczeniu z dnia 5 maja 2010 r. ${ }^{17}$ stwierdził jednoznacznie, że zatrudnienie proboszcza przez parafię ewangelicko-augsburską do posług czysto religijnych nie ma charakteru pracowniczego. SN uznał, że stosunek łączący parafię i proboszcza ma charakter organizacyjny - strony nie zawarły umowy o pracę, nie odprowadzano składek na ubezpieczenie społeczne pracowników, a nadto ustalono mu urlop zgodnie z prawem kościelnym. Jeśli chodzi o duchownego i jego związki z parafią, prawo powszechnie obowiązujące nie określa, na jakiej podstawie prawnej wykonuje on swoje czynności duszpasterskie związane z kultem religijnym. Sprawa wymaga zatem wykładni, w tym wykładni norm Konstytucji RP ${ }^{18}$. Powstaje bowiem pytanie, czy kwestie te pozostawił ustawodawca normom wewnętrznym Kościoła, czy też autonomia tego Kościoła nie sięga aż tak daleko, a status duchownego musi być oceniany zawsze przez pryzmat powszechnie obowiązującego prawa, w tym prawa pracy. W omawianym przypadku cechą wyróżniającą jest bycie duchownym Kościoła i sprawowanie funkcji religijnych na jego rzecz. Zdaniem Sądu Najwyższego orzekającego w niniejszej sprawie, fakt ten stanowi wystarczającą podstawę rozróżnienia statusu zatrudnieniowego, jeśli przy tym weźmie się pod uwagę autonomiczność Kościoła i zasadę konstytucyjną wyrażoną w art. 25 ust. 3. Innymi słowy, wyłączenie pracy proboszcza Kościoła spod działania powszechnego prawa pracy uzasadnia konieczność zabezpieczenia realizacji innej wartości konstytucyjnej, a mianowicie zasady niezależności Kościoła od państwa. Poddanie funkcjonariuszy Kościoła reżimowi zatrudnienia sformułowanemu przez Kościół nie stanowi zatem dyskryminacji w sytuacji, gdy wszyscy duchowni podlegają podobnemu reżimowi, i gdy mamy do czynienia $\mathrm{z}$ dobrowolnym poddaniem się rygorom kościelnym przez osobę, która wykonuje prace związane z kultem sakralnym.

16 Cebula, Pracki, Sobczyk 2017, 300-301.

17 Sygn. I PK 201/09, LEX nr 1036598.

18 Konstytucja Rzeczypospolitej Polskiej z dnia 2 kwietnia 1997 r., Dz. U. Nr 78, poz. 483 z późn. zm. 
Teza o możliwości zatrudniania w oparciu o prawo wewnętrzne kościoła osoby duchownej do posług religijnych wynika też z ustawy o gwarancjach wolności sumienia i wyznania ${ }^{19}$, która zezwala - w zgodzie z wolnością sumienia i wyznania - wybrać stan duchowny lub zakonny, oraz ustawą o stosunku Państwa do Kościoła Ewangelicko-Augsburskiego w Rzeczypospolitej Polskiej ${ }^{20}$, która określa sferę autonomii Kościoła Ewangelicko-Augsburskiego. W myśl art. 1 ustawy, Kościół ten korzysta z pełnej wolności wyznawania swojej wiary oraz wykonywania swojego kultu religijnego. Kościół rządzi się w swoich sprawach wewnętrznych przepisami. Zgodnie zaś z art. 2 ustawy, Kościół jest samodzielny i niezależny od jakiejkolwiek pozakrajowej władzy duchownej i świeckiej. Z art. 9 ustawy z 1994 r. wynika ponadto, że proboszcz jest organem parafii jako osoby prawnej. Taka regulacja generalna wskazuje na przyznanie autonomii Kościołowi w zakresie wykonywania kultu religijnego. Oznacza również swobodę w określaniu statusu osób, które dobrowolnie ten kult wykonują.

Status szczególny tych osób został ustalony w Zasadniczym Prawie Wewnętrznym oraz w Pragmatyce Służbowej Kościoła Ewangelicko-Augsburskiego, wydanej na podstawie \$21 Zasadniczego Prawa Wewnętrznego. W myśl Pragmatyki, urząd duchowny sprawowany jest na podstawie mandatu a proboszcz jest włączony w hierarchię stanowisk, jako ostatni jej szczebel. Ponadto Pragmatyka określa strój służbowy duchownego i prawa socjalno-bytowe, $w$ tym określone prawo do emerytury, do otrzymania mieszkania służbowego, zwrotu kosztów podróży itd., a także stwierdza, że duchowny podlega postępowaniu dyscyplinarnemu.

Status duchownych zakłada hierarchiczne podporządkowanie i władztwo kościelne, co stanowi analogię do statusu funkcjonariusza, a nie do statusu pracownika wykonującego pracę pod kierownictwem tylko w zakresie czasu, miejsca i sposobu jej wykonania. To wszystko wskazuje, że obowiązujący stan prawny w zakresie zatrudniania proboszcza przez para-

19 Ustawa z dnia 17 maja 1989 r. o gwarancjach wolności sumienia i wyznania, tekst jedn. Dz. U. z 2017 r., poz. 1153 z późn. zm.

20 Ustawa z dnia 13 maja 1994 r. o stosunku Państwa do Kościoła Ewangelicko-Augsburskiego w Rzeczypospolitej Polskiej, tekst jedn. Dz. U. z 2015 r., poz.43. 
fię do posług o charakterze czysto religijnym, kreuje odmienny od pracowniczego charakter zatrudnienia ${ }^{21}$.

\section{ZAKRES UPRAWNIEŃ ZWIĄZANYCH Z PEŁNIENIEM URZĘDU DUCHOWNEGO}

Wszyscy duchowni zatrudnieni $\mathrm{w}$ parafii są uprawnieni do prowadzenia lekcji religii, udzielania chrztów ${ }^{22} \mathrm{i}$ asystowania przy zawieraniu małżeństw ${ }^{23}$. W odniesieniu do chrztu należy zauważyć, że nie wolno przyjmować chrztów z sąsiednich parafii bez uprzedniej zgody właściwego proboszcza ${ }^{24}$. Zastrzeżenie to nie dotyczy przypadku chrztu nagłego. $\mathrm{W}$ odniesieniu do małżeństwa należy zauważyć, że miejscem właściwym dla zawierania ślubu kościelnego jest kościół parafialny narzeczonej, jednak na podstawie pisemnej zgody proboszcza parafii narzeczonej, ślub może być przeniesiony na inny teren.

Jeśli chodzi o małżeństwa samych duchownych, są oni zobowiązani do uzyskania uprzedniej pisemnej zgody biskupa Kościoła ${ }^{25}$. Nadto duchowne$\mathrm{mu}$ - pod rygorem skreślenia z listy duchownych - nie wolno zawierać małżeństwa z osobą przynależącą do innego Kościoła, za wyjątkiem tych, które pozostają z KEA we wspólnocie ołtarza i ambony ${ }^{26}$. Na marginesie rozważań warto wspomnieć, że do 1 stycznia 2017 r. duchownymi uprawnionymi do sprawowania Sakramentu Ołtarza byli jedynie prezbiterzy, a diakoni na zasadzie wyjątku, za zgodą biskupa diecezjalnego. Od 1 stycznia 2017 r. ograniczenie to nie obowiązuje. Tym samym - za wyjątkiem uprawnień administracyjnych - diakoni zostali w tym zakresie zrównani z prezbiterami.

Do reprezentowania parafii na zewnątrz i składania w jej imieniu oświadczeń woli jest uprawniony jedynie proboszcz parafii, co obejmuje także upoważnienie do dokonywania wszystkich czynności sądowych

21 Por. wyrok SN z 5 maja 2010 r.

$22 \S 75$ PS.

$23 \S 122$ PS; $\S 42$ ust. 9 Regulaminu Parafialnego, tekst ujednolicony na dzień 24 czerwca 2015 r., https://bik.luteranie.pl/files/Prawo/2015-06-24RegulaminParafialnytekstjednolityBIK.pdf [dostęp: 08.12.2017]; dalej: RegP..

\footnotetext{
$24 \S 71$ PS.

$25 \S 151$ ust. 1 PS.

$26 \S 151$ ust. 2 PS.
} 
i pozasądowych $\mathrm{w}$ imieniu parafii ${ }^{27}$. Czynności przekraczające zakres zwykłego zarządu wymagają uprzedniej zgody Rady Parafialnejej ${ }^{28}$. Dodać należy, że jeśli dokonanie jakiejś czynności prawnej wymaga uzyskania zgody władz kościelnych na mocy prawa kościelnego, czynność prawna wykonana bez takiej zgody jest ex lege nieważna ${ }^{29}$.

\section{UPRAWNIENIA DUCHOWNEGO WYNIKAJĄCE Z FAKTU ŚWIADCZENIA PRACY}

Duchownym przysługuje:

a) prawo do przychodu ze służby,

b) prawo do mieszkania służbowego,

c) prawo do urlopu wypoczynkowego,

d) prawo do korzystania z Funduszu Socjalnego Kościoła,

e) prawo do mieszkania po przejściu na emeryturę ${ }^{30}$.

Emerytowanemu duchownemu Kościół przez swe jednostki organizacyjne zapewnia mieszkanie, co najmniej 2-pokojowe, wyposażone w odpowiednie media. Przysługuje mu też możliwość korzystania z Funduszu Socjalnego Konsystorza. W wypadku śmierci duchownego Kościół przez swe jednostki organizacyjne zapewnia jedno mieszkanie zastępcze osobom najbliższym, zamieszkującym wspólnie z duchownym do dnia jego śmierci: współmałżonkowi - dożywotnio, o ile nie zmieni stanu cywilnego, dzieciom - do osiągnięcia samodzielności ${ }^{31}$. Rozwiązanie to wynika nie tylko ze świadomości prawodawcy, że służba duchownego ma szczególny charakter, ale również z faktu, że małżonki duchownych również wykonują prace na rzecz parafii, czy to przez zaangażowanie w działalność charytatywno-społeczną, czy też w sposób sformalizowany - jako katechetki.

Duchownemu przysługuje 1 dzień wolny od pracy w tygodniu oraz 30 dni kalendarzowych urlopu, a po 25 latach pracy w Kościele, licząc od dnia ordynacji, dodatkowy urlop - 14 dni kalendarzowych ${ }^{32}$. Duchow-

\footnotetext{
$27 \S 42$ ust. 3 RegP.

$28 \quad$ 42 ust. 6 RegP.

$29 \$ 42$ ust. 7 RegP.

$30 \S 198$ ust. 1 PS.

31 Por. §202 PS.

32 Por. $\S \S 203-204$ ust. 1 PS.
} 
ny ma prawo do uzyskania krótkotrwałego, nieprzekraczającego łącznie 30 dni w roku, urlopu na cele szkolenia i dokształcania ${ }^{33}$. Przepis te implikuje zatem potrzebę i konieczność permanentnej formacji duchownych w wymiarze teologiczno-duszpasterskim, ale również potrzebę dokształcania wynikającą z faktu administrowania parafią i jej majątkiem.

Duchowni są zobowiązani do poddawania się wstępnym i okresowym badaniom lekarskim. Tryb poddania się badaniom określa Konsystorz ${ }^{34}$.

Koszty podroży wynikających ze służby duchownego pokrywa jednostka organizacyjna, w której służba ta jest pełniona, a więc parafia, w której duchowny pełni służbę. Pokrycie tych kosztów może odbywać się poprzez: utrzymanie samochodu służbowego, ekwiwalent pieniężny za korzystanie z samochodu dla celów służbowych zgodnie z przepisami lub w formie ryczałtu ustalanego poprzez daną jednostkę organizacyjną ${ }^{35}$.

Wszyscy duchowni Kościoła przechodzą na emeryturę w wieku 65 lat. W wyjątkowych wypadkach Konsystorz na wniosek biskupa Kościoła, poparty pozytywną opinią biskupa diecezjalnego, może przedłużyć duchownemu pełnienie służby w Kościele, nie dłużej jednak niż do ukończenia 68. roku życia ${ }^{36}$. Warto podkreślić, że przepis ten nie różnicuje wieku emerytalnego kobiet i mężczyzn.

\section{UBEZPIECZENIE SPOŁECZNE DUCHOWNYCH \\ I OBOWIĄZKI PODATKOWE}

Osoba duchowna podlega ubezpieczeniom społecznym, tj. obowiązkowo ubezpieczeniom: emerytalnemu, rentowemu i wypadkowemu, oraz dobrowolnie ubezpieczeniu chorobowemu. Składki na ubezpieczenia społeczne osób duchownych finansowane są:

- przez ubezpieczonego w wysokości 20\% a przez Fundusz Kościelny w wysokości $80 \%$ należnej składki na obowiązkowe ubezpieczenia społeczne,

\footnotetext{
$33 \S 204$ ust. 6 PS.

$34 \$ 206$ PS.

$35 \$ 207$ PS.

$36 \S 9$ ust. 1 PS.
} 
- w całości przez ubezpieczonego na dobrowolne ubezpieczenie chorobowe.

Funkcję płatnika składek na własne ubezpieczenia zobowiązana jest pełnić samodzielnie osoba duchowna. Dodać należy, że skoro duchownymi mogą być zarówno kobiety, jak i mężczyźni - odnoszą się do nich również uprawnienia dotyczące wypłaty zasiłku macierzyńskiego. Szczegółowe zasady w tym zakresie określa ustawa o systemie ubezpieczeń społecznych z dnia 13 października $1998 \mathrm{r}^{37}$ oraz ustawa z dnia 25 czerwca 1999 r. o świadczeniach pieniężnych z ubezpieczenia społecznego w razie choroby i macierzyństwa ${ }^{38}$.

Duchowni podlegają obowiązkowi opłaty zryczałtowanego podatku dochodowego na zasadach określonych w ustawie z 20 listopada 1998 r. o zryczałtowanym podatku dochodowym od niektórych przychodów osiąganych przez osoby fizyczne ${ }^{39}$. Osoby duchowne swoje zobowiązanie podatkowe w formie ryczałtowej płacą kwartalnie. Wysokość podatku uzależniona jest od liczby mieszkańców parafii. Liczbę mieszkańców przyjmuje się według stanu na 31 grudnia roku poprzedzającego rok podatkowy, za który opłacany jest ryczałt, według danych właściwych organów administracji miast i gmin, prowadzących ewidencje ludności ${ }^{40}$. Wynika z tego zatem, że podstawą obliczenia wysokości podatku jest liczba mieszkańców danej parafii a nie liczba wiernych. Ryczałt ulega obniżeniu o kwotę składki na ubezpieczenie zdrowotne, opłaconej zgodnie z przepisami o świadczeniach opieki zdrowotnej finansowanych ze środków publicznych bezpośrednio przez osobę duchowną w kwartale, za jaki uiszczany jest ryczałt ${ }^{41}$.

Podkreślić należy, że naczelnik urzędu skarbowego, na wniosek osoby duchownej, może obniżyć stawkę podatku, jeżeli liczba wyznawców na danym terenie stanowi mniejszość w ogólnej liczbie mieszkańców. Osoba duchowna w takiej sytuacji zobowiązana jest dołączyć do wniosku oświadczenie o liczbie wyznawców.

\footnotetext{
37 Tekst jedn. Dz. U z 2016 r., poz. 963.

38 Tekst jedn. Dz. U. z 2017 r., poz. 1368.

39 Tekst jedn. Dz. U. z 2016 r., poz. 2180.

40 Etel, Sitniewski 2002, 11.

41 Tamże,
} 


\section{SKREŚLENIE Z LISTY DUCHOWNYCH}

Skreślenie z listy duchownych następuje w razie śmierci duchownego oraz na mocy uchwały Konsystorza w następujących przypadkach:

a) na pisemny wniosek duchownego,

b) w razie odmowy przyjęcia miejsca pełnienia służby,

c) na podstawie prawomocnego orzeczenia sądu dyscyplinarnego,

d) w innych przypadkach wskazanych w Pragmatyce Służbowej ${ }^{42}$.

Wśród innych przypadków należy wskazać:

1) zawarcie przez duchownego małżeństwa $z$ osobą należącą do innego kościoła, z wyjątkiem osób należących do kościołów pozostających z Kościołem Ewangelicko-Augsburskim w RP we wspólnocie ołtarza i ambony; ,zgodnie z wnioskowaniem a minori ad maius i wykładnią celowościową należy przepis ten także stosować do małżeństwa z osobą niebędącą członkiem żadnego kościoła chrześcijańskiego", tj. wyznawców innych religii lub osób bezwyznaniowych ${ }^{43}$ - skreślenie na wniosek biskupa Kościoła;

2) pozbawienie praw z ordynacji w razie wystąpienia duchownego z Kościoła $^{44}$

3) decyzja biskupa Kościoła i Rzecznika Dyscyplinarnego o braku zdolności do piastowania urzędu duchownego w związku z rozwodem duchownego ${ }^{45}$.

Ostatni z wskazanych powodów może się wydawać kontrowersyjny, nie mniej jednak wynika on ze szczególnego charakteru służby duchownego, z którym związana jest też jego osobista postawa. Kluczowe znaczenie dla decyzji Konsystorza mają w takim przypadku okoliczności rozwodu, które mogą przesądzać o pozostawieniu duchownego w służbie, ale skutkować koniecznością zmiany parafii.

Uchwały Konsystorza mają rygor natychmiastowej wykonalności. Przepis dopuszcza ponowne wpisanie na listę duchownych przez Konsystorz na pisemny wniosek duchownego, jeśli skreślenie z listy nastąpiło

\footnotetext{
$42 \S 6$ pkt b PS.

43 Hucał 2017, 798.

$44 \S 20$ ust. 9 ZPW.

$45 \S 151$ ust. 3 PS.
} 
na jego wniosek. W takim przypadku wskazane jest uzasadnienie wniosku przez duchownego. Jednakże w tym przypadku Konsystorz cieszy się pełną swobodą w zakresie uwzględnienia wniosku.

\section{PODSUMOWANIE}

Wydaje się, że prawo wewnętrzne Kościoła Ewangelicko-Augsburskiego w sposób pełny i wyczerpujący reguluje kwestie charakteru prawnego służby duchownego. Nie mniej jednak zastanawiające jest formalne rozróżnienie między diakonami a prezbiterami w związku z wprowadzoną od 1 stycznia 2017 r. zmianą skutkującą sprawowaniem Sakramentu Ołtarza przez diakonów. W obecnej sytuacji bowiem diakoni jedynie nie mogą pełnić funkcji administracyjnych związanych z zarządzaniem parafią, podczas gdy uprawnienia liturgiczno-sakramentalne są analogiczne. Oczywiście, należy mieć na uwadze toczącą się od wielu lat w Kościele dyskusję na temat ordynacji prezbiterskiej kobiet, które może uzasadniać wprowadzenie takiego rozwiązania, jednakże z punktu widzenia argumentu racjonalności prawodawcy, podejście takie nie jest uzasadnione i stanowi istotne wyzwanie przy przyszłej - planowanej - reformie prawa kościelnego.

\section{BIBLIOGRAFIA}

Artykuły Szmalkaldzkie. 1999. W: Księgi Wyznaniowe Kościoła Luterańskiego. Bielsko-Biała: Augustana.

Cebula, Jakub, Roman Pracki, Arkadiusz Sobczyk. 2017. „Wokacja i kadencja”.

W: Prawo Kościoła Ewangelicko-Augsburskiego. Komentarz, red. Jakub Cebula, 298-302. Warszawa.

Etel, Leonard, Piotr Sitniewski. 2002. „Opodatkowanie kościołów oraz osób duchownych w Polsce". Biuro Studiów i Ekspertyz IV/02, nr 888: 1-20, http:// biurose.sejm.gov.pl/teksty_pdf/i-888.pdf [dostęp: 8.12.2017].

Hucał, Michał. 2017. „Lista duchownych”. W: Prawo Kościoła Ewangelicko-Augsburskiego. Komentarz, red. Jakub Cebula, 794-799. Warszawa.

Milerski, Bogusław. 2004. „Urząd duchowny w teologii Marcina Lutra i księgach wyznaniowych". Rocznik Teologiczny 1: 5-22.

Obrona wyznania augsburskiego. 1999. W: Księgi Wyznaniowe Kościoła Luterańskiego. Bielsko-Biała: Augustana. 


\section{THE LEGAL CHARACTER OF THE MINISTRY OF THE CLERGY IN THE EVANGELICAL-AUGSBURG CHURCH IN THE REPUBLIC OF POLAND}

\section{Summary}

The aim of this article is to present the legal character of the ministry of the clergy - a deacon, a vicar, and a parish priest - in the Evangelical Church of the Augsburg Confession in the Republic of Poland. Since diocesan bishops also typically perform the function of parish priests, which largely determines their formal situation, their legal status is not considered in the present study. The analysis of the legal situation of service of the clergy is based on the acts of ecclesiastical law, including in particular the Fundamental Internal Law and the regulations specifying the rights and obligations of the clergy of the Evangelical-Augsburg Church in Poland (Pragmatyka Stużbowa).

The office of the clergyman in the Evangelical Church of the Augsburg Confession comes from God. However, it has also its legal dimension, which is defined in the Fundamental Internal Law. The Lutheran Church recognizes one office with the threefold order of ministry: a bishop, a presbyter, and a deacon. The ecclesiastical office is not hierarchical - all of the orders of the ecclesiastical office are equal, although they do differ in terms of duties. What unites them is their shared authority to exercise the Power of the Keys, and thus to forgive or retain sins, proclaim the Gospel, and administer the sacraments. The ordination is not sacramental in its character. The law of the Church specifies the terms and conditions of ordination, the rights and duties of the clergy, as well as the rules of appointing to office and removing clergymen from the list of the clergy.

Key words: clergyman; deacon; vicar; parish priest; church law; EvangelicalAugsburg Church; churches and other religious organization 